\title{
Contents Change According to Location of Cabbage in Storage and Effects of Storage Temperature and Film Package on Quality of Cabbage Harvested in Summer Season
}

\author{
NAgAi Kousuke*, Fukushima Akira*, Ogawa Takuya*, \\ MatsuURA Katsuhiko* and Nakagawa Katsuya* \\ *Hyogo Prefectural Hokubu Agricultural Institute \\ Yasui, Wadayama-cho, Asako-gun, Hyogo 669-52 Japan
}

\begin{abstract}
Effects of the storage temperature on freshness, respiration rate and chemical components in cabbage (Brassica oleracea L. var. capitate L.) harvested in the summer season were studied. The cabbage was stored at $5{ }^{\circ} \mathrm{C}, 10^{\circ} \mathrm{C}$ and $15^{\circ} \mathrm{C}$, and the chemical components in different parts from outside to the inside were measured. During storage at $20^{\circ} \mathrm{C}$, the total sugar content in all parts of cabbage decreased, whereas during storage at $5{ }^{\circ} \mathrm{C}$, that in the most outside part of cabbage decreased slightly. The pattern of the decrease of sucrose/total sugar ratio (SU/TS ratio) in the central part of cabbage was different from that in the most outside part. In the central part, the $\mathrm{SU} / \mathrm{TS}$ ratio during storage at all temperatures showed no change, but in the most outside part, the ratio decreased greatly during storage at $15^{\circ} \mathrm{C}$ and $20^{\circ} \mathrm{C}$. The ascorbic acid content in all parts of cabbage decreased proportionately as the storage temperature became high, and that in the most outside part decreased significantly. The respiration rate decreased slowly during storage at all of the temperatures. The respiration rate of $1 / 2$ cut-type ( $1 / 2$ type) cabbage was higher than that of non-cut type (whole-type) cabbage at harvest, and those of the 2 types became almost the same after 7 days of storage. The quality of cabbage, which was harvested in the summer season and then packaged with the package of LDPE (thickness: $30 \mu \mathrm{m}$ ), was kept for about 2 weeks in the whole-type, and for 5 to 7 days in the $1 / 2$ type, respectively, during storage at $5^{\circ} \mathrm{C}$. It is suggested that the decrease of ascorbic acid content in the most outside part of the cabbage during storage can be shown as a magnified value of the decrease in the whole (non-cut) cabbage.
\end{abstract}

(Received Apr.4, 1997)

Fresh cabbage, especially lightly processed (fresh-cut) cabbage is in high demand these days ${ }^{1)}$. The cabbage harvested in the summer season and the lightly processed cabbage deteriorate easily. The primary factors of the decrease of freshness in cabbage are water loss and decrease of several chemical components ${ }^{2) 4}$. In this study, we dealt with the characteristics of respiration and the storage life of cabbage harvested in the summer season and the effects of the storage temperature on the chemical contents in 4 parts divided from the outside to the inside of the cabbage.

\section{Materials and Methods}

\section{Plant material}

Cabbage (Brassica oleracea L. var. capitate L.) used in this experiment was cultivated in the experiment fields at the Hyogo Prefectural Hokubu Agricultural Institute, and harvested on July, 1995. Cultivars and lines used for this experiment were 'SE', '90-6605', 'YRFLATSAWA 3 GO', 'KO -250', 'RAIYO' and 'YR 517'. The 
temperature of the cabbage was $27^{\circ} \mathrm{C}$ at harvest.

Forms of cabbage were 2 types of whole (noncut) and $1 / 2$ cut.

Cabbage was packaged with LDPE (Low density polyethylene $440 \times 300 \mathrm{~mm}$, thickness: $30 \mu \mathrm{m})$ and stored at $5{ }^{\circ} \mathrm{C}, 15^{\circ} \mathrm{C}$ and $20^{\circ} \mathrm{C}$ in the dark for 14 days. The relative humidity was kept between 70 and 85 $\%$ during storage.

In order to investigate the changes of chemical components, cabbage were divided into four parts, after storage for 14 days from the outside to the inside.

\section{Analyses of sugar and ascorbic acid}

The composition of sugar was measured with HPLC (model L-6000 produced by Yanaco Co.). The condition of HPLC was as follows. column; LICHROSORB NH2, mobile phase; acetnitrile (methyl cyanide): methanol: $\mathrm{H}_{2} \mathrm{O}=75: 10: 15$, column temperature; $35^{\circ} \mathrm{C}$, flow rate; $0.8 \mathrm{~m} \ell / \mathrm{min}$.

Ascorbic acid was measured with a $\mathrm{VC}$-meter (model: VC-100 produced by Horiba Co.) after extraction with $0.5 \%$ solution of metaphosphoric acid. The sacorbic acid content was expressed per $100 \mathrm{~g}$ dry weight in order to remove the influence of wilt.

\section{Determination of respiration rate and water content}

The sample was kept in a desiccator (glass) fitted with a rubber stopper on the lid for sampling, and $\mathrm{CO}_{2}$ was measured directly after sealing and again an interval of 2 hours later with a gasanalyzer (model: MAP - T 3000 produced by Sumitomobake Co.).

The water contents were measured after drying for 24 hours at $110^{\circ} \mathrm{C}$.

\section{4 . Sensory evaluation}

Five sensory panels were introduced to determine the 'Fresh score'. The panelist evaluated the fresh score by ranking on a 5 -point scale with 5 to $1 ; 5 \cdots$ the state of cabbage immediately after harvest, $4 \cdots$ cabbage slightly wilt and high value, $3 \cdots$ cabbage considerably wilter but still having value, $2 \cdots$ low value (edible), $1 \cdots$ non-edible.

\section{Results and Discussion}

\section{Effects of the storage temperature on chemical components in 4 different parts of cabbage}

Fig.1 shows the effects of the storage temperature on total sugar content in 4 parts of cabbage. The total sugar content was higher in the

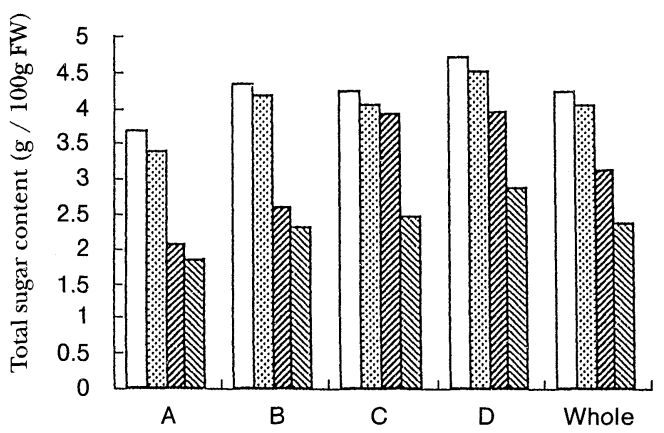

Fig. 1 Effects of storage-temperature on total sugar content in 4 parts of cabbage 'SE'

A $\cdots$ outermost part

B $\cdots$ second part from outside

C...second part from center

D $\cdots$ central part

Whole $\cdots$ average of $\mathrm{A}, \mathrm{B}, \mathrm{C}$ and $\mathrm{D}$

$\square$ day

. 14 days storage at $5{ }^{\circ} \mathrm{C}$

14 days storage at $15^{\circ} \mathrm{C}$

$\mathbb{N} 14$ days storage at $20^{\circ} \mathrm{C}$

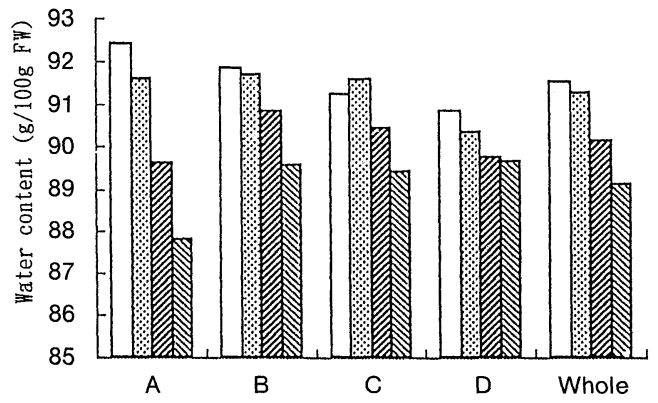

Fig. 2 Effects of storage-temperature on water content in 4 parts of cabbage 'SE'

A $\cdots$ outermost part

$\mathrm{B} \cdots$ second part from outside

C $\cdots$ second part from center

D...central part

Whole $\cdots$ average of A, B, C and D

$\square \quad 0$ day

14 days storage at $5{ }^{\circ} \mathrm{C}$

14 days storage at $15^{\circ} \mathrm{C}$

14 days storage at $20^{\circ} \mathrm{C}$ 


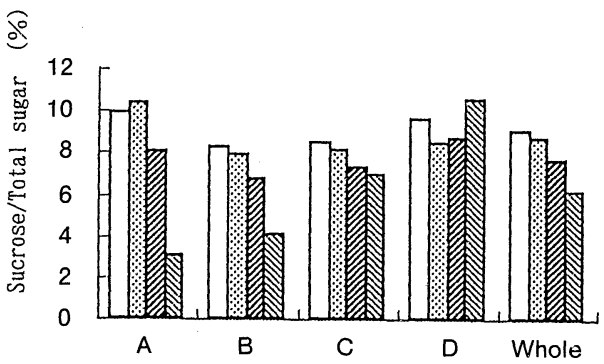

Fig. 3 Effects of storage-temperature on sucrose / total sugar rate in 4 parts of cabbage ' $\mathrm{SE}$ '

A $\cdots$ outermost part

B $\cdots$ second part from outside

C $\cdots$ second part from center

D...central part

Whole *average of $\mathrm{A}, \mathrm{B}, \mathrm{C}$ and $\mathrm{D}$

$\square \quad 0$ day

14 days storage at $5{ }^{\circ} \mathrm{C}$

14 days storage at $15^{\circ} \mathrm{C}$

14 days storage at $20^{\circ} \mathrm{C}$

central part than in the other parts at harvest.

As storage temperature became high, the total sugar content decreased markedly. In all parts of the cabbage, the total sugar content decreased significantly during storage at $20{ }^{\circ} \mathrm{C}$. The total sugar content decreased slightly in the central part at $15^{\circ} \mathrm{C}$ and showed little change in outermost part at $5^{\circ} \mathrm{C}$.

As shown in Fig.2. The water content decreased proportionately as the storage temperature became high. In the central part, the decrease of water content showed a minimal change during storage, even at $20^{\circ} \mathrm{C}$. On the other hand, water content in the outermost part decreased greatly as storage temperature became higher.

YAMASHITA et $a l .{ }^{2)}$ reported that the total sugar in cabbage decreased during storage. ABE et $a l .{ }^{5)}$ and NAGAI et al..$^{4)}$ also demonstrated that the total sugar in mume fruit and onion decreased during storage. These results are in agreement with the findings of this study.

Considering the water loss, the total sugar in the outermost part decreased markedly as compared with that in the other parts. Total sugar decreased more significantly in the outside part than in the central part, suggesting that the decrease of sugar content in the central part could be restrained by

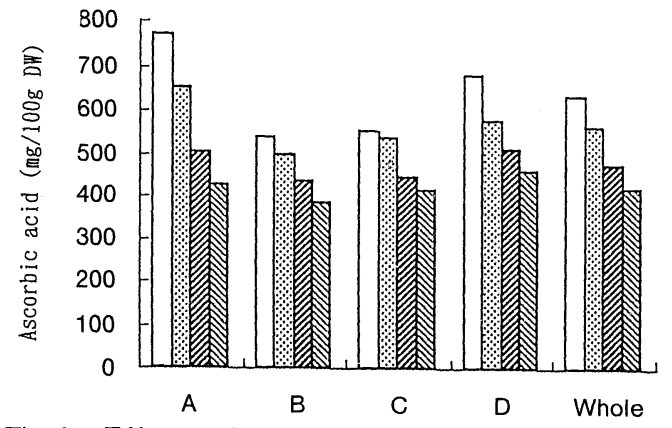

Fig. 4 Effects of storage-temperature on ascorbic acid content in 4 parts of cabbage ' $\mathrm{SE}$ '
A $\cdots$ outermost part
B $\cdots$ second part from outside
C $\cdots$ second part from center
D...central part
Whole $\cdots$ average of $\mathrm{A}, \mathrm{B}, \mathrm{C}$ and $\mathrm{D}$
$\square \quad 0$ day
14 days storage at $5{ }^{\circ} \mathrm{C}$
14 days storage at $15^{\circ} \mathrm{C}$
$\mathbb{N} 14$ days storage at $20^{\circ} \mathrm{C}$

the decrease in the outside part.

Fig.3 shows the effects of the storage temperature on the SU/TS ratio in 4 parts of caggage. The SU/TS ratio in the outermost part and the central part was higher than that in the other parts at harvest. As storage temperature became higher, the SU/TS ratio decreased in a whole cabbage. However, the pattern of the decrease during storage differed among the parts of the cabbage. In the central part, the decrease of SU/TS ratio during storage was slight regardless of the temperature of the storage. The SU/TS ratio decreased slightly in the second part from the center ( $\mathrm{C}$ part) during storage at $20^{\circ} \mathrm{C}$. In the outermost outside part, the SU/TS ratio decreased significantly during storage at $15^{\circ} \mathrm{C}$ and $20^{\circ} \mathrm{C}$. As the second part from the outside (B) was near the outermost part, the pattern of the decrease of SU/ TS ratio was intermediate between those of the outermost part and C. At $5^{\circ} \mathrm{C}$ storage, the SU/TS ratio decreased slightly in all parts. The SU/TS ratio decreased strongly at $20^{\circ} \mathrm{C}$ in the outermost part. These findings were also noted in broccoli by YAMASHITA et al. ${ }^{3)}$

A slight decrease of SU/TS ratio occurred at $5{ }^{\circ} \mathrm{C}$, but it was significant at $20^{\circ} \mathrm{C}$, which could imply that the quantity of reduced sugar decreased 
Table 1 Respiration rates of cabbage of several cultivars at harvest and during storage at $5^{\circ} \mathrm{C}$

\begin{tabular}{|c|c|c|c|c|c|c|c|}
\hline \multirow{4}{*}{ Cultivar } & \multirow{4}{*}{$\begin{array}{l}\text { Fresh } \\
\text { weight } \\
(\mathrm{g})\end{array}$} & \multicolumn{6}{|c|}{ Respiration rate $\left(\mathrm{CO}_{2} \mathrm{mg} / \mathrm{Kg} / \mathrm{hr}\right)$} \\
\hline & & \multicolumn{3}{|c|}{ Non-cut } & \multicolumn{3}{|c|}{$1 / 2$ cut } \\
\hline & & \multicolumn{3}{|c|}{ storage period (days) } & \multicolumn{3}{|c|}{ storage period (days) } \\
\hline & & $0 *$ & 4 & 7 & $0 *$ & 4 & 7 \\
\hline $\mathrm{SE}$ & 1005 & 17.1 & 18.3 & 12.8 & 26.3 & 25.9 & 10.6 \\
\hline $90-6605$ & 1238 & 12.8 & 14.8 & 13.1 & 22.9 & 20.4 & 15.2 \\
\hline YRSAWA 3GO & 1453 & 13.7 & 18.2 & 10.9 & 25.4 & 21.8 & 12.5 \\
\hline $\mathrm{KO}-250$ & 1192 & 16.4 & 18.5 & 13.7 & 27.1 & 22.8 & 10.4 \\
\hline RAIYO & 795 & 23.8 & 25.1 & 18.2 & 41.6 & 34.4 & 15.6 \\
\hline YR517 & 869 & 20.3 & 20.5 & 15.4 & 36.2 & 30.6 & 18.4 \\
\hline
\end{tabular}

* Respiration rates of ' 0 day': measured after 4 hours storage at $5{ }^{\circ} \mathrm{C}$

Table 2 Respiration rates of cabbage of several cultivars at harvest and during storage at $15^{\circ} \mathrm{C}$

\begin{tabular}{|c|c|c|c|c|c|c|c|}
\hline \multirow{4}{*}{ Cultivar } & \multirow{4}{*}{$\begin{array}{c}\text { Fresh } \\
\text { weight } \\
\text { (g) }\end{array}$} & \multicolumn{6}{|c|}{ Respiration rate $\left(\mathrm{CO}_{2} \mathrm{mg} / \mathrm{Kg} / \mathrm{hr}\right)$} \\
\hline & & \multicolumn{3}{|c|}{ Non-cut } & \multicolumn{3}{|c|}{$1 / 2$ cut } \\
\hline & & \multicolumn{3}{|c|}{ storage period (days) } & \multicolumn{3}{|c|}{ storage period (days) } \\
\hline & & $0 *$ & 4 & 7 & $0 *$ & 4 & 7 \\
\hline SE & 983 & 35.4 & 28.3 & 23.8 & 61.3 & 30.2 & 17.9 \\
\hline $90-6605$ & 1086 & 33.6 & 25.4 & 19.7 & 66.2 & 24.3 & 18.1 \\
\hline YRSAWA $3 G O$ & 1357 & 31.8 & 25.8 & 22.1 & 64.5 & 26.6 & 16.8 \\
\hline KO-250 & 1366 & 36.1 & 27.1 & 23.4 & 62.8 & 25.8 & 22.5 \\
\hline RAIYO & 858 & 50.2 & 33.5 & 24.1 & 86.7 & 38.5 & 22.8 \\
\hline YR517 & 906 & 42.9 & 30.1 & 22.8 & 69.3 & 34.7 & 21.2 \\
\hline
\end{tabular}

* Respiration rates of ' 0 day': measured after 4 hours storage at $15^{\circ} \mathrm{C}$

by the respiration and so on was more than that of reduced sugar which reacted chemically from sucrose at such a high temperature as $20^{\circ} \mathrm{C}$.

The effects of the storage temperature on ascorbic acid content in 4 parts of cabbage are shown in Fig.4. Ascorbic acid content in the outermost part was higher than that in the other parts at harvest. Ascorbic acid content decreased in all parts of cabbage proportionately with the height of storage temperature.

It is well-known that ascorbic acid content can be used as an index of freshness ${ }^{3), 6)}$. The quantity and the ratio of the decrease on ascorbic acid content was much greater in the outermost part than in the other parts. Moreover, the pattern of the decrease in the outermost part was the same in that in the whole cabbage.
Therefore, we suggested that the decrease of ascorbic acid content in the outermost part of cabbage during storage can be shown as a clear sign or the magnified value of the decrease in the whole cabbage.

\section{Relationship between the resporation rate and cultivar or cut type}

The respiration rate of several cultivars during storage at $5^{\circ} \mathrm{C}$ is shown in Table 1 . The respiration rate of 'RAIYO' at harvest was the highest of all cultivars in both the whole-type and $1 / 2$ cut type. The respiration rate of the $1 / 2$ type was 1.5 to 1.8 times as high as that of the whole-type at harvest. In the whole-type, the respiration rate after 7 days of storage at $5^{\circ} \mathrm{C}$ was lower than that at harvest, whereas that in the $1 / 2$ cut type after 4 days of storage was lower than that at harvest. 
Table 3 Fresh score of non-packed cabbage during storage at $5^{\circ} \mathrm{C}$

\begin{tabular}{|c|c|c|c|c|c|c|c|c|c|}
\hline \multirow{4}{*}{ Cultivar } & \multirow{4}{*}{$\begin{array}{c}\text { Fresh } \\
\text { weight } \\
(\mathrm{g})\end{array}$} & \multicolumn{8}{|c|}{ Fresh score* } \\
\hline & & \multicolumn{4}{|c|}{ Non-cut } & \multicolumn{4}{|c|}{$1 / 2$ cut } \\
\hline & & \multicolumn{4}{|c|}{ storage period (days) } & \multicolumn{4}{|c|}{ storage period (days) } \\
\hline & & 2 & 4 & 7 & 14 & 2 & 4 & 7 & 14 \\
\hline $\mathrm{SE}$ & 965 & 4.8 & 4.5 & 4.2 & 3.5 & 4.5 & 3.5 & 2.5 & 1.5 \\
\hline $90-6605$ & 1128 & 4.8 & 4.5 & 4.3 & 3.5 & 4.5 & 3.2 & 2.4 & 1.7 \\
\hline YRSAWA 3GO & 1372 & 4.8 & 4.5 & 4.3 & 3.6 & 4.5 & 3.4 & 2.5 & 1.6 \\
\hline KO-250 & 1249 & 4.8 & 4.5 & 4.3 & 3.6 & 4.5 & 3.5 & 2.3 & 1.5 \\
\hline RAIYO & 895 & 4.8 & 4.2 & 3.5 & 2.8 & 4.5 & 2.2 & 1.5 & 1.0 \\
\hline YR517 & 826 & 4.8 & 4.3 & 4.0 & 3.2 & 4.5 & 3.0 & 2.0 & 1.0 \\
\hline
\end{tabular}

* Fresh score: from 5: excellent to 1 : not edible

Table 4 Fresh score of cabbage packed with $\mathrm{PE}$ film during storage at $5^{\circ} \mathrm{C}$

\begin{tabular}{|c|c|c|c|c|c|c|c|c|c|}
\hline \multirow{4}{*}{ Cultivar } & \multirow{4}{*}{$\begin{array}{c}\text { Fresh } \\
\text { weight } \\
(\mathrm{g})\end{array}$} & \multicolumn{8}{|c|}{ Fresh score* } \\
\hline & & \multicolumn{4}{|c|}{ Non-cut } & \multicolumn{4}{|c|}{$1 / 2$ cut } \\
\hline & & \multicolumn{4}{|c|}{ storage period (days) } & \multicolumn{4}{|c|}{ storage period (days) } \\
\hline & & 2 & 4 & 7 & 14 & 2 & 4 & 7 & 14 \\
\hline $\mathrm{SE}$ & 1020 & 5.0 & 4.8 & 4.5 & 4.0 & 4.8 & 4.5 & 4.2 & 3.3 \\
\hline $90-6605$ & 1163 & 5.0 & 4.8 & 4.5 & 4.0 & 4.8 & 4.5 & 4.1 & 3.1 \\
\hline YRSAWA 3GO & 1294 & 5.0 & 4.8 & 4.5 & 4.0 & 4.8 & 4.5 & 4.2 & 2.8 \\
\hline $\mathrm{KO}-250$ & 1411 & 5.0 & 4.8 & 4.5 & 4.0 & 4.8 & 4.5 & 4.0 & 3.0 \\
\hline RAIYO & 875 & 5.0 & 4.8 & 4.5 & 4.0 & 4.8 & 4.3 & 3.5 & 2.5 \\
\hline YR517 & 950 & 5.0 & 4.8 & 4.5 & 4.0 & 4.8 & 4.5 & 3.7 & 2.7 \\
\hline
\end{tabular}

* Fresh score: from 5: excellent to 1 : not edible

After 7days of storage, the respiration rate of the $1 / 2$ type was almost the same height as that of the whole-type.

The respiration rate of several cultivars during storage at $15{ }^{\circ} \mathrm{C}$ is shown in Table 2. The respiration rate during storage at $15^{\circ} \mathrm{C}$ was higher than that at $5^{\circ} \mathrm{C}$. At harvest, the respiration rate at $15^{\circ} \mathrm{C}$ was 2 to 3 times as high as that of $5^{\circ} \mathrm{C}$. The respiration rate of 'RAIYO' was the highest of all cultivars at $15^{\circ} \mathrm{C}$. At harvest the respiration rate of the $1 / 2$ type was 1.6 to 2.0 times as high as that of the whole-type.

In both the whole-type and $1 / 2$ type, the respiration rate was reduced gradually during storage at $15^{\circ} \mathrm{C}$, and the respiration rate of the $1 / 2$ type was lower than that of the whole-type after 7 days of storage.
There was a difference of the respiration rate among cultivars. 'RAIYO', of which the respiration rate was the highest, was a cultivar for nonheattreated ( uncooked) food, and the leaves of 'RAIYO' were tender. The leaves of 'YR517' were harder than that of 'RAIYO', and more tender than that of 'SE' (data not shown).

Therefore, we suggested that the respiration rate of the cultivar of cabbage with tender leaves could be high.

\section{Periods of preservation quality of cabbage harvested in summer season}

The fresh score of non-packed cabbage during storage at $5^{\circ} \mathrm{C}$ is shown in Table 3 . We defined a high fresh state as being 4 or above of the fresh score. The high fresh state was maintained for about 1 week in the whole-type and for 2 to 3 days 
in the $1 / 2$ type, except for 'RAIYO'. The preiod during which 'RAIYO' maintained a high fresh was the shortest of all cultivars in both the whole-type and the $1 / 2$ type.

As is apparent in Table 4, freshness was kept for about 2 weeks in the whole-type and for 5 to 7 days in the $1 / 2$ type cabbage packed with $\mathrm{PE}$ film at $5^{\circ} \mathrm{C}$. The difference of the storage life among cultivars became smaller with film packaging than with non-packaging. The difference of the storage life among cultivars was insignificant in the whole -type.

$\mathrm{O}_{2}$ permeability of $\mathrm{PE}$ film in this study was 7,100 $\left(\mathrm{m} \ell / \mathrm{m}^{2} \cdot \text { day } \cdot \mathrm{atm}\right)^{7)}$, and it was judged that $\mathrm{O}_{2}$ density decreased and $\mathrm{CO}_{2}$ density increased in the film during storage (data not shown). We thought that the period of keeping quality in cabbage was prolonged by controlling water content and reapiration rate with film packaging.

The period of keeping freshness was prolonged by combining $5^{\circ} \mathrm{C}$ storage with film packaging, which could suggest that the technique was very useful in the control of the shipment on weekends and the harvest season.

We thank Prof. YAMAUCHI of Yamaguchi University for his valuable suggestions.

This study was presented at the 44th Meeting of the Japanese Society for Cold Preservation of Food (1996).

\section{Literature Cited}

1) NAGAI, K., ARIKATA, T., OGAWA,T. and NAKAGAWA, K.: Kinki Chugoku Agr. Res., 89, 45 50 (1995)

2) Yamashita, I., NAgATA, M., DAN, K., KAWAI, M., Imo, Y., Watanabe. K., TAmura, T., Shimose, H. and Mizuno, K.: $J$. Japan. Soc. Cold Preserva. Food, 20, 137 142 (1994)

3) YAMASHITA, I. and KoBAYASHI, K.: J. Japan. Soc. Cold Preserva. Food, 19, 8 13 (1993)

4) Nagai, K., SaWa, M., YoshikaWa, T., Kishimoto., M., YamadA, M., NAKAGAWA,
Y. and ISA, S.: I Japan. Soc. Cold Preserva. Food, 18, 141 147 (1992)

$5)$ ABe, K., Morita, A. and Yamada, K.: $J$. Japan. Soc. Cold Preserva. Food, 18, $5 \sim 10$ (1992)

6) Goto, M., Murakami, M., Yamada, K.: $J$. Japan. Soc. Cold Preserva. Food, 15, 10 17 (1989)

7 ) OTA, H., KodA, H., NAKATANi,A., Shina, T., IJIRI, T. and IshiTAni, T.: J. Japan. Soc. Cold Preserva. Food, 17, 106 111 (1991)

\section{夏季収穫キャベツにおける貯蔵中の 部位別成分变化および貯蔵温度, フィルム包装が品質保持に及ぼす影響}

\author{
永井 耕介* ·福嶋 昭* - 小河 拓也* \\ 松浦 克彦*.中川 勝也* \\ *兵庫県立北部農業技術センター
}

（テ669-52 兵庫県朝来郡和田山町安井123）

夏季収穫キャベツの部位別成分に及ぼす貯蔵温度の影 響を調査するとともに呼吸特性・鮮度保持期間について 検討した。

1. 貯蔵温度が高いほど全糖含量の減少は著しかった。 $20^{\circ} \mathrm{C}$ では全ての部位で咸少がみられたが， $5{ }^{\circ} \mathrm{C} て ゙ は$ 外 葉部での減少もわずかであった。

2. ショ糖/全糖割合における貯蔵温度別の減少パ夕 一ンは中心部と外葉部とでは異なっていた。中心部では

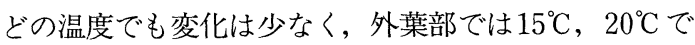
減少がみられた。

3.ビタミンCは全ての部位で貯蔵温度が高いほど減 少した。外葉部での減少が著しいので，外葉部のビタミ ンC含量を測定することにより貯蔵中のビタミンC含量 の変化をより明確にできることがわかった。

4. 収穫後の呼吸量は低温で咸少し, 同心゙保存温度で その後漸减した。収穫直後の $1 / 2$ カット形態はホール

（無カット）形態よりも呼吸量は多いが，1週間後では 両形態ともほぼ同量の呼吸量に減少した。

5. 夏季高温時収穫のキャベツは $5{ }^{\circ} \mathrm{C}$ 貯藏条件とフィ

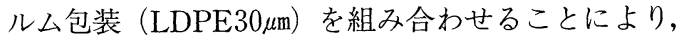
ホール形態では 2 週間程度, $1 / 2$ カット形態でも 5 ～７日間高鮮度を保持することが可能である。

(平成 9 年 4 月 4 日受理) 